\title{
A Study on the College English Teaching Reform Based on the \\ Cultivation of Applied Talents
}

\author{
Cuiping $\operatorname{Han}^{1, a}$ \\ ${ }^{1}$ Xi'an Peihua University, Xi'an City, Shaanxi Province, 710125, China
}

\begin{abstract}
Keywords: College English; Applied Talents; Teaching Teform; Guarantee Measures
\end{abstract}
\begin{abstract}
With the transformation of higher education from elite education to mass education in China, the social and individual needs for English talents are multi-level and pay more attention to the practicality of talents. Under the overall framework of applied talents training, the reform of English teaching is imperative. Based on the author's learning and practical experience, this paper first analyzed the path of college English curriculum reform, and then put forward the guarantee measures to promote college English curriculum reform. In this paper, the author pointed out that the school can guarantee the reform of college English course by carrying out the graded teaching, credit system and strengthening the construction of teaching staff.
\end{abstract}

\section{Introduction}

The reform of College English teaching is related to the economic development of our country at the same time, and it is the reform of the foreign language that under the premise of the economic development to a certain extent. That is to say, the reform of College English teaching is in line with the political and economic development of the country, and the level and the standard of the demand for English talents are also changing with the development of the national political economy to a certain extent. At the same time, the demand of the society and the students for English has been adjusted with the change of the economic development. At present, China is becoming more and more frequent in international communication, and the demand for the comprehensive application ability of college students is increasing, especially the demand of the international communication ability which is based on listening and speaking ability. College English serves professional development and career orientation, which is the driving force for college students to learn English well. Therefore, it is one of the most urgent problems in the current English teaching that how to deepen the reform to adapt to the requirements of the times, to make the right choice and to develop in the right direction.

\section{The Path of College English Curriculum Reform}

A single course turns to a hierarchical curriculum module. For a long time, the vast majority of colleges and universities set four semester College English courses for Non English Majors. The nature of curriculum is the basic course of general English, which is unified and unitary. According to the orientation and diversification of the training objectives of applied talents, College English curriculum is based on three levels: General requirements, higher requirements and much higher requirements, to build a hierarchical and diversified curriculum system. It needs to add "practical module courses (skill enhancement classes), general purpose module courses (Language and Culture), ESP courses (ESP) to meet the needs of different language proficiency and ability, so 
that students of different English proficiency can be selected for their own courses. The College English curriculum framework is shown in figure 1.

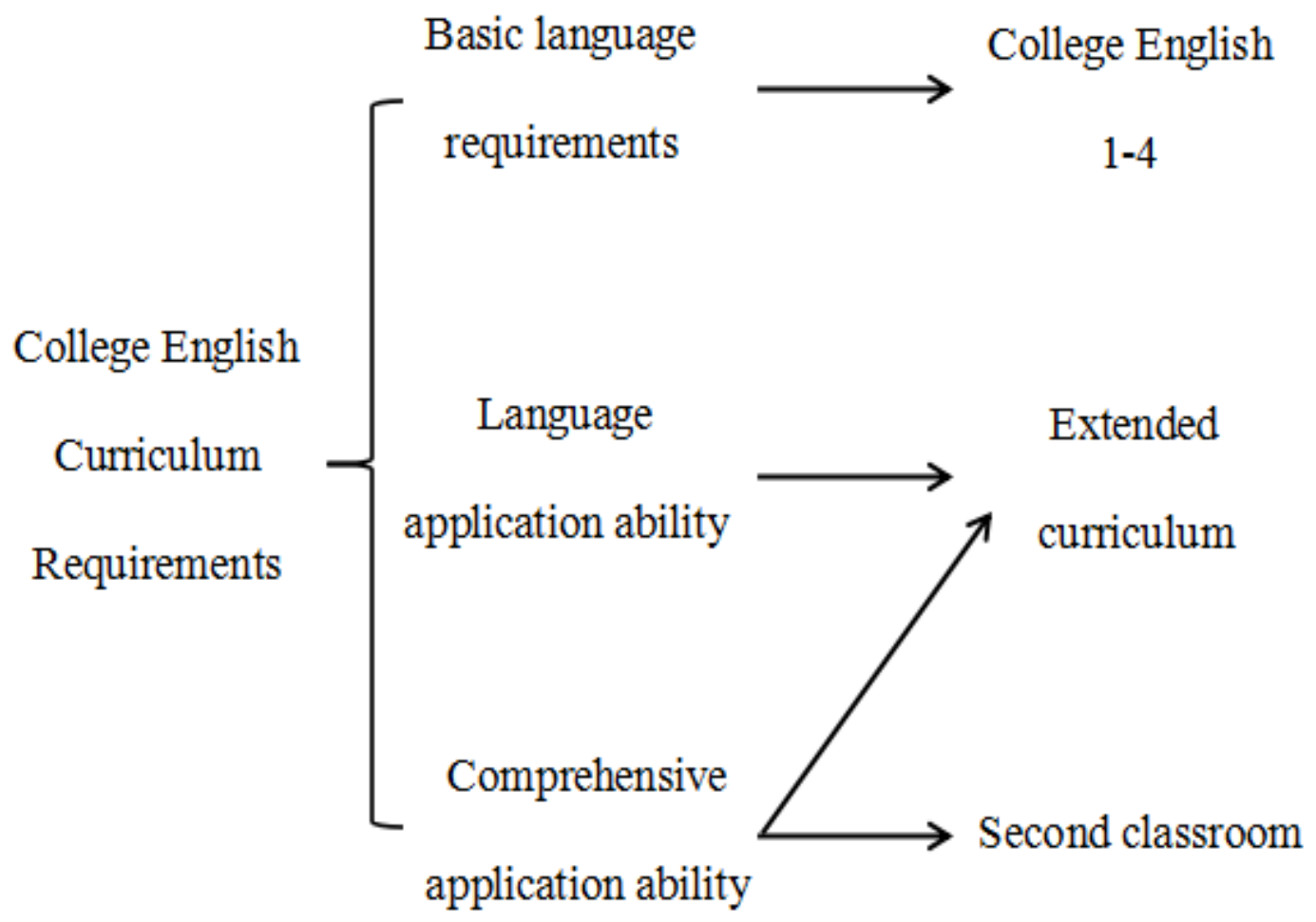

Fig.1 College English Curriculum Framework

The basic English course module includes College English preparatory class, I IV class reading and listening, to cultivate students' basic skills in listening, speaking, reading, writing and translating, and to lay a solid foundation for the study of English learning module. This requires the completion in the freshman or sophomore phase to use uniform textbooks. After the completion of the teaching plan, they will meet or close to the four level of College English requirements. English enhancement courses include Chinese and English comparison and Translation, interpreting, Chinese cultural English reading, secretarial English and business negotiation, to cultivate students' communicative competence and application ability and improve students' English literacy and literary appreciation ability, so that it can lay the foundation for further study of English and Bilingual Courses. This is mainly conducted in the 3 7 semester for students who reach level four or close to the level of four. Students choose courses according to their own personal interests and development needs to improve the comprehensive ability of English, professional English skills and comprehensive quality through the study.

Single classroom turns to stereoscopic teaching mode with the internal and external combination. A single model of Teacher centered traditional classroom teaching should turn to the teaching mode of combining classroom teaching with network platform independent learning, the importance of the second class in College English Teaching is more prominent. Stereoscopic teaching mode is based on students' self practice and combined with the first and second classroom, and it pays attention to the development of personality and the ability of continuous learning. The aim is to make students' language knowledge turn into language application ability. The three-dimensional teaching mode is shown in Figure 2. 


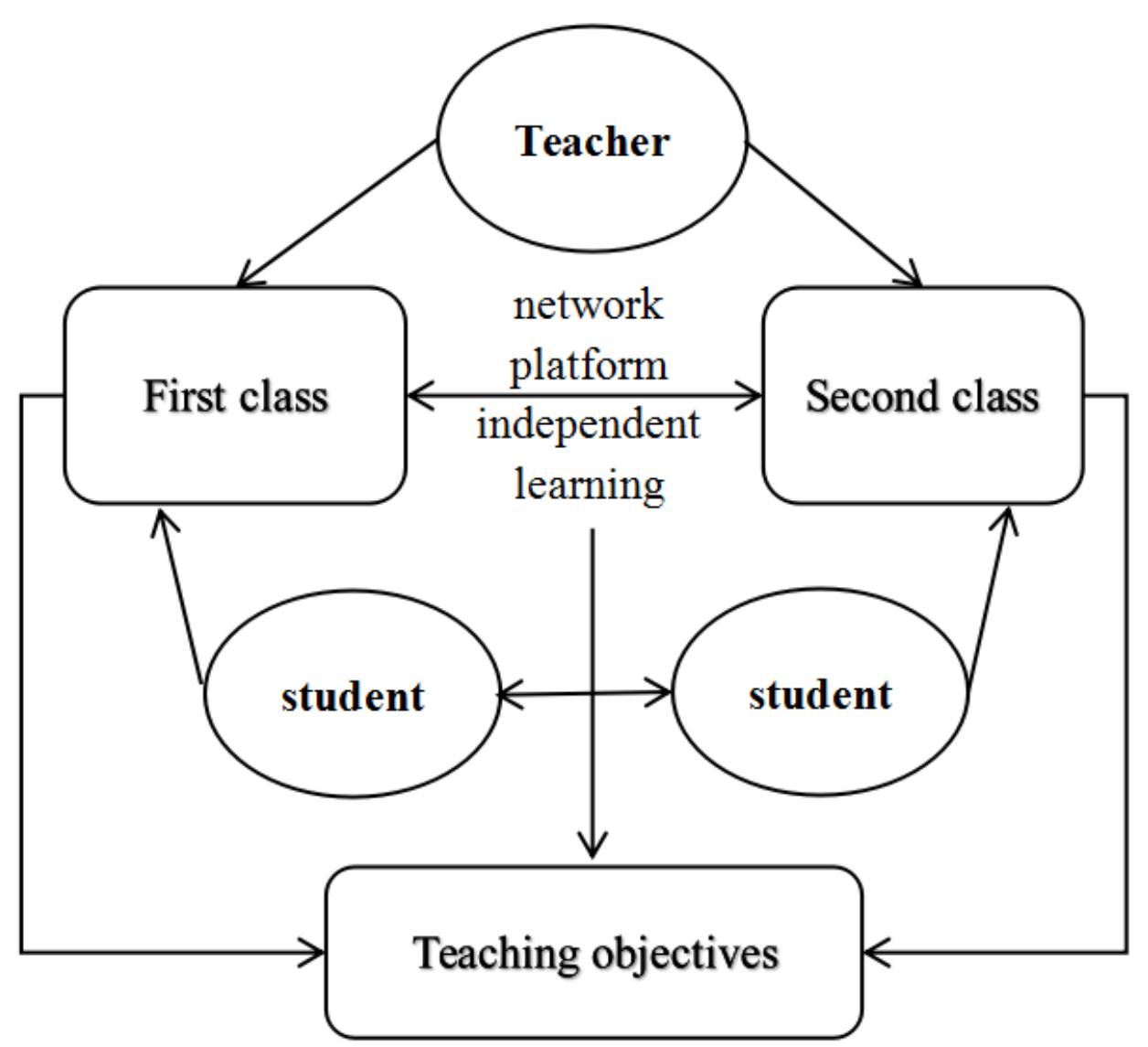

Fig.2 The three-dimensional teaching mode is shown in

The combination of the first and the second classes can expand the learning space for students, which is conducive to achieve a three-dimensional teaching of students' curriculum learning, autonomous learning and extracurricular practice learning. In the first class, the teacher face to face teaching is conducive to make the students master the language and cultural knowledge,so the main purpose is to build language knowledge, cultivate English reading and writing ability. Through a lot of language input and practice, network platform independent learning enables students to complete a large number of language skills training, to strengthen the ability of knowledge development and promote the ability of independent inquiry and the development of learning ability. In the second class, a series of activities outside the classroom teaching are carried out around the goal of College English Teaching, such as spoken English skills competition, oral translation contest, writing competition, etc., which provides students with a variety of meaningful language practice activities, so it can improve language application and communication skills by the extracurricular practice.

Unified compulsory basic course type turns to diversified curriculum types. After the college English curriculum system of Applied Talents Training replaced the single nature of College English Course, the development of the course will be limited to elective courses. Students with higher English proficiency can be exempt from compulsory courses. The combination of required courses and elective courses can meet the needs of a wide range of English learning, which can provide students with a wide range of choices and development of personality space, to ensure that the different levels of students in the application of English has been fully trained and improved. Compulsory and elective courses can promote the formation of students' English literacy, therefore, elective courses and required courses should complement each other. According to the curriculum goal, the student's level and the curriculum demand, Compulsory and elective courses should be 
diversified, but also hierarchical.

\section{The Guarantee Measures to Promote College English Curriculum Reform}

Grading teaching and credit system are the premise. The group of College English curriculum and the variety of curriculum types embody the teaching principle of "teaching requirements", which fully reflects the personality, and considers the different starting point of students. It not only takes care of the students with lower starting point, but also creates the development space for the better students; It not only can help students lay a solid foundation of language, but also can develop their practical ability; It not only guarantees the steady improvement of the students' English level in the whole university, but also is beneficial to the students' individual learning and to meet the needs of their different professional development. Graded teaching must ensure that different levels of students in the application of English proficiency has been fully trained and improved, laying the foundation for the establishment and management of the curriculum. The credit system can meet the needs of diversified courses, and increase the freedom of teaching and learning space, and it meets the needs of individualized teaching, and provides the possibility for the overall planning and implementation of the curriculum.

Strengthening the construction of teaching staff is the key. When cultivating students' comprehensive ability of English application and improving the overall quality of College English education in China, College English teachers' professional quality is the key, because it will affect the success or failure of College English teaching, whether the curriculum reform can be carried out smoothly. Teachers are the core of teaching, and the reform of curriculum means the change of teachers' educational ideas and teaching methods, therefore, it has a higher demand for teachers after the course of College English has changed from a single basic course into several modules. College English teachers should not only have the language knowledge, but also have extensive knowledge, so they can accurately understand and interpret the information conveyed by language. College English teaching is not only the analysis and explanation of language knowledge, but also the integration of the language knowledge into practice, so it needs to strengthen students' ability to apply when imparting knowledge. It can be seen that the improvement of teachers' comprehensive quality and the optimization of knowledge structure are the guarantee for the smooth progress of College English curriculum reform. To strengthen the construction of teaching staff, curriculum reform can achieve the desired results.

Teaching evaluation system is a supplement. Three dimensional teaching model of classroom, network self study and extracurricular practice have expanded the learning space, so the degree of freedom and randomness of students' learning is also increasing. In order to avoid students to participate in the course of learning and Practice for the purpose of earning credits, to improve the participation and enthusiasm of students' course selection, to ensure that the second classroom learning is not a mere formality, it needs a clear and reasonable evaluation mechanism as a guarantee. Second classroom should be taken into College English teaching evaluation system to assess students' learning process, to scientifically and comprehensively evaluate the performance of the students in the second class. 


\section{Summary}

The reform of College English Curriculum in the period of transformation is an attempt, meeting the requirements and objectives of the school personnel training, providing a broad space for learning for different levels of students, so it will bring new vitality and vigor to college English Teaching in the future. By full support of the school and the joint efforts of teachers, college English curriculum reform is bound to advance smoothly.

\section{References}

[1] Zeng Ling. Exploration of applied college English teaching reform[J]. Journal of Hubei University of Economics (HUMANITIES AND SOCIAL SCIENCES EDITION), 2014, (04): 208-209.

[2] Dong Yan, Ke Yinggen. A study on the orientation of College English teaching reform in Applied Undergraduate Universities[J]. Jiangsu Higher Education, 2014, (04): 99-100.

[3] Zhang Jian. A university applied newly established college English curriculum reform[J]. The Science Education Article Collects, 2012 (11): 96-97.

[4] Qu Sheming, Luan Hong. A study on the cultivation of Applied Talents in College English teaching [J]. Educational Review, 2012, (02): 102-104.

[5] Qin Qiu. Quality education and College English Teaching Reform[J]. Nanjing Social Science, 2015, (04): 71-73.

[6]Lu Xiaoyong. Applied linguistics and College English Teaching Reform[J]. Foreign Language, 2012, (04): 39-44. 